\title{
UV-Visible Spectrophotometric Method for the Estimation of Rilpivirine Hydrochloride in Pharmaceutical Dosage Form by Using Multivariate Technique
}

\author{
K. VIJAYA SRI*, G.VINAY JAIN and M. MADHURI
}

Department of Pharmaceutical Analysis, Malla Reddy College of Pharmacy, Maisammaguda, Secunderabad-500 014, Andhra Pradesh, India

vijayasree_2002@yahoo.co.in

Received 20 August 2014 / Accepted 5 September 2014

\begin{abstract}
To develop a simple, precise and accurate UV-method with multivariate calibration technique for estimation of rilpivirine hydrochloride in pharmaceutical dosage form. This technique is based on the use of the linear regression equations by using relationship between concentration and absorbance at five different wavelengths like 301, 303, 305, 307 and $309 \mathrm{~nm}$. The results were treated statistically and were found highly accurate, precise and reproducible. The rilpivirine hydrochloride shows absorption maxima at $305 \mathrm{~nm}$ and obeyed Beer's law in the range of 0.5-3.0 $\mu \mathrm{g} / \mathrm{mL}$. The \% recovery of tablets was found to be in the range of $101.1-101.7 \%$. The limit of detection (LOD) and limit of quantification (LOQ) were found to be 0.358 and $1.086 \mu \mathrm{g} / \mathrm{mL}$, respectively. The low \% RSD values are indicates the accuracy and precise of the method. The proposed methods can be successfully applied for method development, validation and multivariate analysis of rilpivirine hydrochloride.
\end{abstract}

Keywords: Rilpivirine hydrochloride, UV spectroscopy, Development, Validation, Multivariate technique

\section{Introduction}

Rilpivirine hydrochloride is a di-amino pyrimidine derivative. Chemically, it is 4-[[4-[[4- $[(E)-$ 2-cyanoethenyl]-2,6-dimethylphenyl]amino]-2-pyrimidinyl]amino]benzonitrile monohydrochloride structure is shown in Figure 1. Rilpivirine hydrochloride is a human immunodeficiency virus type 1 (HIV-1) specific non-nucleoside reverse transcriptase inhibitors (NNRTI) indicated for used in single and combination of other drugs like tenofovir, emcitribine and effarveniz. Rilpivirine (TMC278) is NNRTI, which was approved ${ }^{1-3}$ by the FDA in May 2011. It is a basic, white, amorphous powder which is readily soluble in methanol, dichloromethane and insoluble in water. Rilpivirine hydrochloride is not yet official in I.P and B.P. A thorough literature survey revealed that UV spectroscopy ${ }^{4-6}, \mathrm{HPLC}^{7-9}$ method for rilpivirine hydrochloride with combination of other drugs, UPLC ${ }^{10}, \mathrm{LC}^{-M S}{ }^{11}$, for its estimation in bulk, pharmaceutical dosage forms and biological samples. 
<smiles>Cc1cc(/C=C/C#N)cc(C)c1Nc1ccnc(Nc2ccc(C#N)cc2)n1</smiles>

Figure 1. Chemical structure of rilpivirine hydrochloride

There is no reported method for multivariate technique in UV studies for the estimation of rilpivirine hydrochloride. Multivariate calibration refers to the process of constructing a mathematical model that relates a property such as content or identity to the absorbance of a set of known reference samples at more than one wavelength ${ }^{12}$. If the absorbance of an analyte $(Z)$ is measured at five wavelengths set, straight line equation can be written as; $A_{\lambda}=\mathrm{aX}(\mathrm{Cz}+\mathrm{k})$ where $\mathrm{A}_{\lambda}$ represent the absorbance of the analyte, $\mathrm{A}$ is the slope and $\mathrm{k}$ is the intercept of the linear regression function of the analyte. $\mathrm{C}_{Z}$ represents the concentration of analyte. At five selected wavelengths, the equation system can also be summed as; $A_{T}=a X\left(C_{Z}+b\right) X\left(C_{Z}+c\right) X\left(C_{Z}+d\right) X\left(C_{Z}+e\right) X$ $\left(\mathrm{C}_{\mathrm{Z}}+\mathrm{K}_{\mathrm{T}}\right)$, which can be simplified to $\mathrm{A}_{\mathrm{T}}=\mathrm{C}_{\mathrm{Z}}(\mathrm{a}+\mathrm{b}+\mathrm{c}+\mathrm{d}+\mathrm{e})+\mathrm{K}_{\mathrm{T}}$ where $\mathrm{a}, \mathrm{b}, \mathrm{c}, \mathrm{d}$, e are the slopes, $\mathrm{A}_{\mathrm{T}}$ and $\mathrm{K}_{\mathrm{T}}$ represents the sum of absorbance obtained and sum of intercepts of regression equations at five-wavelength set respectively. The concentration of the $Z$ analyte in a mixture can be calculated by using the Eqn. $C_{Z}=A_{T}-K_{T} /(a+b+c+d+e)$. The present research work on the application of UV spectral multivariate calibration technique having simple mathematical content for the quantitative determination of rilpivirine hydrochloride in pharmaceutical formulation. UV Spectrophotometric methods of analysis are more economic and simpler, compared to methods such as chromatography and electrophoresis.

\section{Experimental}

Rilpivirine hydrochloride was gift sample from Hetero Laboratories Ltd. (Hyderabad, A.P, India). Methanol was purchased from Merck Chemical Company, India. The commercially tablets are not available in Indian market, hence we have manufactured immediate release tablet containing $25 \mathrm{mg}$, acacia, micro crystalline cellouse, lactose, magnesium sterate and talc from S D Fine Chem. Ltd. (Mumbai, India).

\section{Instruments}

The multivariate technique was performed in double beam UV-Vis spectrophotometer (UV1800, Shimadzu, Japan) connected to computer loaded with spectra manager software UV Probe was employed with spectral bandwidth of $1 \mathrm{~nm}$ and wavelength accuracy of $\pm 0.3 \mathrm{~nm}$ with a pair of $10 \mathrm{~mm}$ matched quartz cells and sonicator.

\section{Preparation of standard stock solution of rilpivirine hydrochloride}

Standard stock solution of rilpivirine hydrochloride $(1 \mathrm{mg} / \mathrm{mL})$ was prepared by transferring $10 \mathrm{mg}$ of rilpivirine hydrochloride into a $10 \mathrm{~mL}$ volumetric flask containing $4 \mathrm{~mL}$ of $(8: 2)$ methanol and water. It was then sonicated for 15 minutes and solution was diluted up to the volume by methanol and water. From these, further dilutions were made using $(8: 2)$ methanol and water to produce solution of rilpivirine hydrochloride $(100 \mu \mathrm{g} / \mathrm{mL})$.

\section{Selection of wavelength for analysis of rilpivirine hydrochloride}

$0.1 \mathrm{~mL}$ of standard stock solution of rilpivirine hydrochloride was transferred into a $10 \mathrm{~mL}$ volumetric flask and diluted to a mark with methanol: water $(8: 2)$ to give concentration of $1 \mu \mathrm{g} / \mathrm{mL}$. The resulting solution was scanned in the UV range $(200-400 \mathrm{~nm})$. 


\section{Preparation of sample solution}

Twenty tablets are analysed for their drug content by UV spectrophotometric methods. The tablet contents were crushed into a fine powder and suitably diluted in methanol: water (8:2) to yield a concentration of $1.0 \mathrm{mg} / \mathrm{mL}$ for rilpivirine hydrochloride. The mixture was sonicated to dissolve, make up the volume with methanol: water $(8: 2)$. The above solutions were filtered through Whatman filter paper and the solution was transferred into volumetric flask and was made up to the mark with methanol: water (8:2) to obtain a final concentration of $1.5 \mu \mathrm{g} / \mathrm{mL}$. The spectrum was recorded at $305 \mathrm{~nm}$ against blank solution of methanol: water (8:2).

\section{Validation of proposed method}

The method was validated according to ICH guidelines in order to determine the linearity, precision, accuracy and ruggedness of the method.

\section{Linearity}

Linearity was evaluated by seven point standard curve in concentration range of $0.5-3.5 \mu \mathrm{g} / \mathrm{mL}(0.5,1,1.5,2,2.5,3$ and $3.5 \mu \mathrm{g} / \mathrm{mL})$ of rilpivirine hydrochloride. The calibration curve was obtained by plotting absorbance against concentration $(\mu \mathrm{g} / \mathrm{mL})$ for five different wavelengths. Each set was analyzed to plot a calibration curve. Standard deviation (SD), slope, intercept and correlation coefficient of determination $\left(\mathrm{r}^{2}\right)$ of the calibration curves were calculated to ascertain the linearity of the method.

\section{Method precision (repeatability)}

The precision of the instrument was checked by repeated scanning and measurement of the absorbance of solution $(\mathrm{n}=6)$ for rilpivirine hydrochloride $(1.5 \mu \mathrm{g} / \mathrm{mL})$ without changing the parameter of the proposed UV method. The \%RSD was calculated.

\section{Intermediate precision (reproducibility)}

The intraday and interday precision of the proposed method was determined by analyzing the corresponding responses on the same day and next day for three different concentration of standard solution of rilpivirine hydrochloride $(0.5,1.5$ and $2.5 \mu \mathrm{g} / \mathrm{mL})$. The result was reported in terms of relative standard deviation (\%RSD).

\section{Accuracy}

Accuracy of the proposed method was determined using recovery studies by standard addition method. The recovery studies were carried out by adding different amounts $(50,100$ and $150 \%)$ of the pure drug to the pre-analysed formulation. The solutions were prepared in triplicates and the $\%$ recovery was calculated.

\section{Limit of detection and limit of quantitation}

The parameters LOD and LOQ were determined on the basis of response and slope of the regression equation. The limit of detection (LOD) and the limit of quantitation (LOQ) of the drug were derived by calculating the signal-to-noise ratio ( $\mathrm{S} / \mathrm{N}$, i.e., 3.3 for LOD and 10 for LOQ) using the following equations designated by International Conference on Harmonization $(\mathrm{ICH})$ guidelines.

$$
\mathrm{LOD}=3.3 \times \sigma / \mathrm{S}, \mathrm{LOQ}=10 \times \sigma / \mathrm{S}
$$

Where $\sigma=$ the standard deviation of the response and $\mathrm{S}=$ slope of the calibration curve 


\section{Ruggedness studies}

Ruggedness studies were performed by preparing three replicates of $1.5 \mu \mathrm{g} / \mathrm{mL}$, analysing by two different analyst and on two different instruments and the results are reported as $\%$ RSD.

\section{Results and Discussion}

In spectrum, rilpivirine hydrochloride in pharmaceutical dosage form shows maximum absorbance at $305 \mathrm{~nm}$ shown in Figure 2.

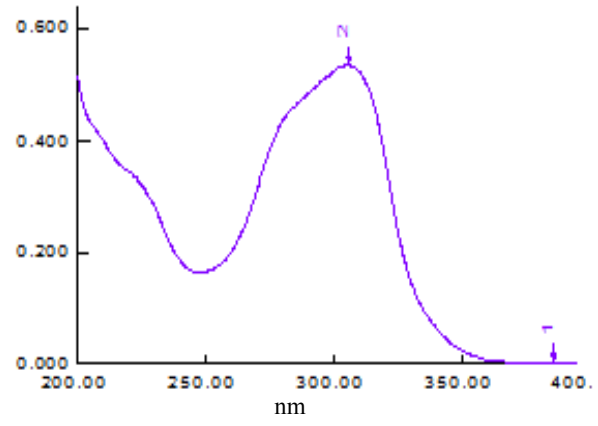

Figure 2. Absorbtion spectra of rilpivirine hydrochloride in pharmaceutical formation

\section{Method validation}

The proposed method was validated as per ICH guidelines in order to determine the linearity, precision, accuracy and ruggedness of the method.

\section{Linearity}

Standard solutions of rilpivirine hydrochloride in the concentration range of 0.5 to $3.5 \mu \mathrm{g} / \mathrm{mL}$ were observed in UV spectroscopy at $305 \mathrm{~nm}$. A graph of absorbance (on Y-axis) versus concentration (on X-axis) was plotted (overlay of absorbance) was shown in Figure 3. In order to improve this correlation and minimize instrumental fluctuations, absorbances of these solutions were measured over a range surrounding $305 \mathrm{~nm}$ i.e., 301, 303, 307, $309 \mathrm{~nm}$ are shown in Table 1. The calibration curves of rilpivirine hydrochloride at different wavelengths are shown in Figure 4.

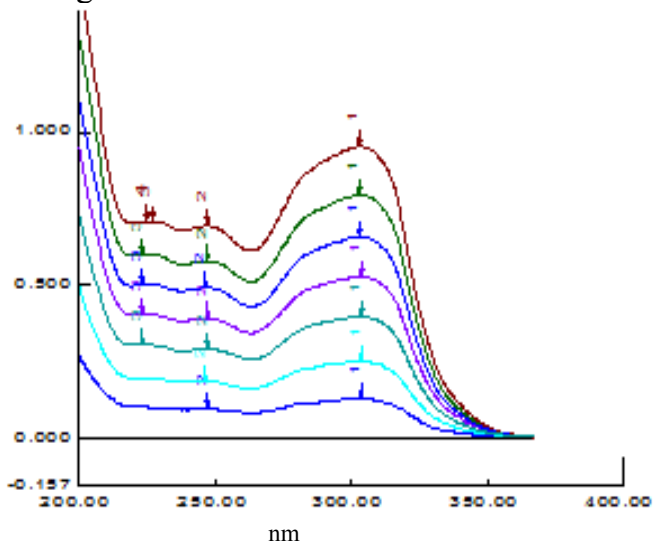

Figure 3. Overlay spectra of rilpivirine hydrochloride in pharmaceutical formation 
Table 1. Calibration data of proposed method by using multivariate technique

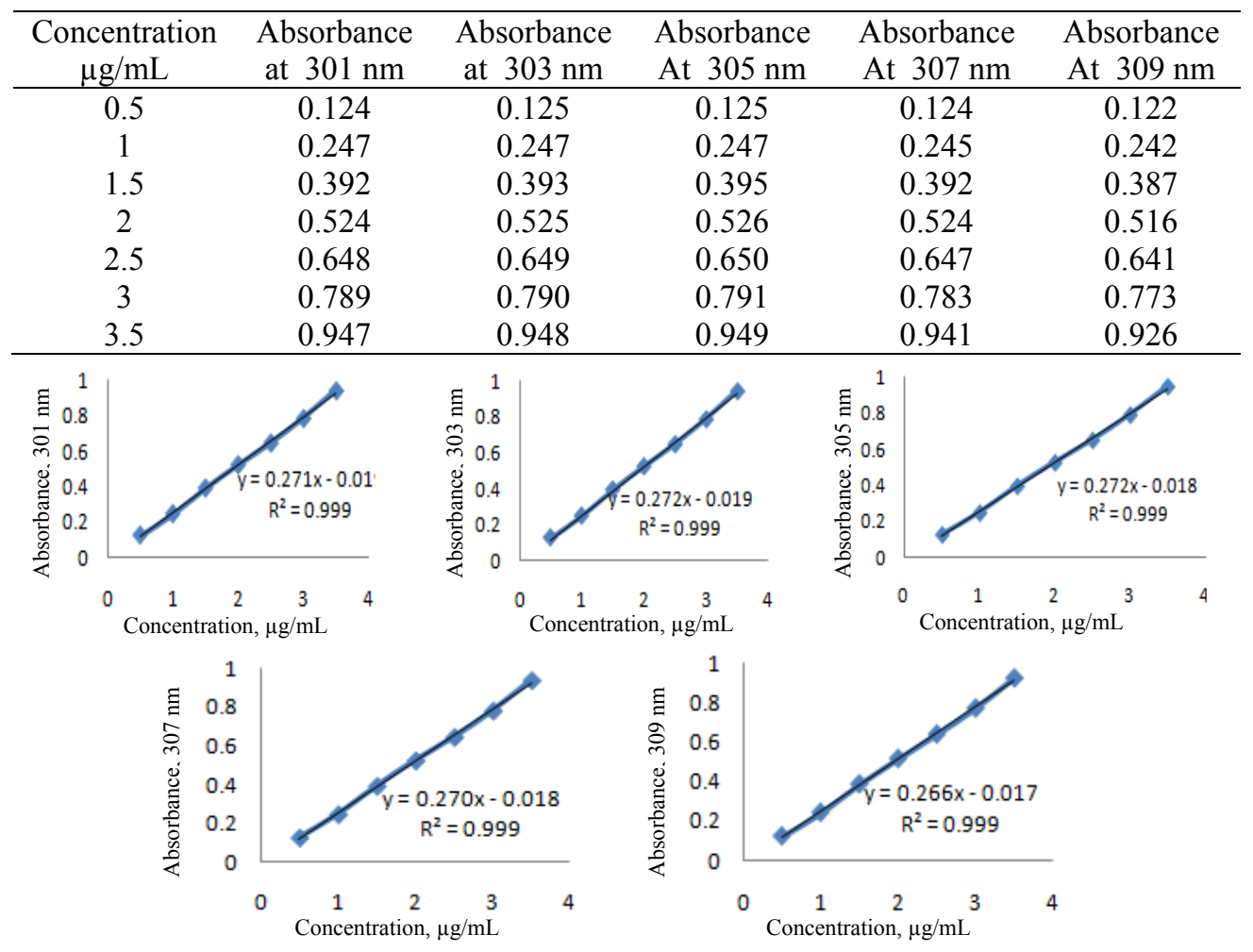

Figure 4. Calibration curves of rilpivirine hydrochloride showing maximum absorbance at $301,303,305,307$ and $309 \mathrm{~nm}$

\section{Method precision (repeatability)}

Repeatability was determined by analyzing $1.5 \mu \mathrm{g} / \mathrm{mL}$ concentration of rilpivirine hydrochloride for six times and calculated the $\%$ RSD was found to be $<2$ which shown in Table 2.

Table 2. Repeatability studies of rilpivirine hydrochloride

\begin{tabular}{cccl}
\hline $\begin{array}{c}\text { Concentration } \\
\mu \mathrm{g} / \mathrm{mL}\end{array}$ & $\begin{array}{c}\text { Absorbance } \\
\text { at } 305 \mathrm{~nm}\end{array}$ & $\begin{array}{c}\text { Absorbance } \\
\text { Mean } \pm \mathrm{SD}\end{array}$ & $\% \mathrm{RSD}$ \\
\hline 1.5 & 0.382 & & \\
1.5 & 0.392 & & \\
1.5 & 0.385 & $0.386 \pm 0.004$ & 1.03 \\
1.5 & 0.389 & & \\
1.5 & 0.385 & & \\
1.5 & 0.382 & & \\
\hline
\end{tabular}

\section{Intermediate precision (reproducibility)}

The precision of the developed method was expressed in terms of percent relative standard deviation (\% RSD). These results show reproducibility of the assay. The \% RSD values were found to be less than 2 that indicate this method precise for the determination of the pure form. The interday and intraday precision results were mentioned in Table 3. 
Table 3. Intraday and Interday precision of rilpivirine hydrochloride

\begin{tabular}{ccccc}
\hline $\begin{array}{c}\text { Concentration } \\
\mu \mathrm{g} / \mathrm{mL}\end{array}$ & $\begin{array}{c}\text { Absorbance mean } \pm \\
\text { S.D. }(\mathrm{n}=3)\end{array}$ & \%RSD & $\begin{array}{c}\text { Absorbance mean } \pm \\
\text { S.D. }(\mathrm{n}=3)\end{array}$ & \%RSD \\
\hline 0.5 & $0.125 \pm 0.002$ & 1.60 & $0.127 \pm 0.002$ & 1.55 \\
1.5 & $0.384 \pm 0.005$ & 1.23 & $0.385 \pm 0.005$ & 1.19 \\
2.5 & $0.650 \pm 0.003$ & 0.47 & $0.655 \pm 0.009$ & 1.44 \\
\hline
\end{tabular}

Accuracy

Accuracy is determined by performing recovery studies at 3 levels in which known amount of analyte shall be added and recovery shall be carried out in three replicates of each concentration level and the $\%$ recovery was calculated. The mean recovery was found between 100.1-100.7\% and \% RSD between 0.3-0.7. The accuracy results are shown in Table 4.

Table 4. Recovery studies of rilpivirine hydrochloride

\begin{tabular}{|c|c|c|c|c|c|c|}
\hline $\begin{array}{c}\text { Spiked } \\
\text { level, \% }\end{array}$ & $\begin{array}{l}\text { Formulation } \\
\text { Conc, } \mu \mathrm{g} / \mathrm{mL}\end{array}$ & $\begin{array}{c}\text { Pure } \\
\text { Drug conc } \\
\mu \mathrm{g} / \mathrm{mL}\end{array}$ & $\begin{array}{c}\text { Amount Conc } \\
\text { recovered } \\
\mu \mathrm{g} / \mathrm{mL}\end{array}$ & $\begin{array}{c}\% \\
\text { Recovery }\end{array}$ & $\begin{array}{c}\% \text { Mean } \\
\text { recovery } \pm \\
\text { S.D } \\
\end{array}$ & $\% \mathrm{RSD}$ \\
\hline \multirow[t]{3}{*}{50} & 1 & 0.5 & 1.50 & 100.2 & $100.7 \pm 0.339$ & 0.336 \\
\hline & 1 & 0.5 & 1.51 & 100.9 & & \\
\hline & 1 & 0.5 & 1.51 & 100.4 & & \\
\hline \multirow[t]{3}{*}{100} & 1 & 1 & 2.01 & 100.7 & $100.3 \pm 0.604$ & 0.603 \\
\hline & 1 & 1 & 2.00 & 100.2 & & \\
\hline & 1 & 1 & 1.99 & 99.5 & & \\
\hline \multirow[t]{3}{*}{150} & 1 & 1.5 & 2.51 & 100.4 & $100.1 \pm 0.652$ & 0.651 \\
\hline & 1 & 1.5 & 2.52 & 100.7 & & \\
\hline & 1 & 1.5 & 2.49 & 99.4 & & \\
\hline
\end{tabular}

Limit of detection and limit of quantitation

The parameters LOD and LOQ were determined on the basis of response and slope of the regression equation. LOD and LOQ values are 0.358 and 1.086 .

\section{Ruggedness studies}

This study was performed by analyzing $1.5 \mu \mathrm{g} / \mathrm{mL}$ by two different analysts and on two instruments, results of the study were given in Table 5 and \% RSD obtained was less than 2 which is within the acceptance limits.

Table 5. Ruggedness of rilpivirine hydrochloride

\begin{tabular}{ccccc}
\hline Parameter & $\begin{array}{c}\text { Concentration, } \\
\mu \mathrm{g} / \mathrm{mL}\end{array}$ & Absorbance & $\begin{array}{c}\text { Absorbance mean } \\
\pm \text { S.D. }(\mathrm{n}=3)\end{array}$ & \%RSD \\
\hline Different & & 0.382 & & \\
Analyst & 1.5 & 0.386 & $0.386 \pm 0.005$ & 1.17 \\
& & 0.391 & & \\
Different & 1.5 & 0.383 & & 1.16 \\
instrument & & 0.388 & $0.388 \pm 0.005$ & \\
\hline
\end{tabular}




\section{Application of the proposed method for pharmaceutical formulation}

The proposed method was able to remove the interferences of the other excipients present in the pharmaceutical formulations (tablets) are assessed with a high percent of recovery. The percentage recovery for tablet formulation was found to be $99-101 \%$ enlisted in Table 6 . The results for assay are within acceptable limits.

Table 6. Results of Assay

\begin{tabular}{cccc}
\hline Labeled amount, mg & $\begin{array}{c}\text { Amount taken for } \\
\text { assay, } \mu \mathrm{g} / \mathrm{mL}\end{array}$ & $\begin{array}{c}\text { Amount found } \\
\mu \mathrm{g} / \mathrm{mL}\end{array}$ & $\%$ Recovery \\
\hline 25 & 1.0 & 1.0 & 100 \\
25 & 1.0 & 1.01 & 101 \\
25 & 1.0 & 0.99 & 99.2 \\
\hline
\end{tabular}

\section{Conclusion}

The above proposed UV method is very simple, precise, accurate, rapid and cost effective for the quantification of rilpivirine hydrochloride from its pharmaceutical dosage forms by the multivariate spectrophotometric method. The method requires only the wave length scan and the solvent is also very cheaper when compared the other methods. Hence it can be utilized for routine analysis in bulk and pharmaceutical dosage forms.

\section{References}

1. $\quad$ Stellbrink H J, Eur J Med Res., 2007, 12(9), 483-495.

2. Miller C D, Crain J and Tran B, Drugs Today, 2011, 47, 5-15; DOI:10.1358/dot.2011.47.1.1583188

3. Ripamonti D and Maggiolo F, Curr Opi Inves Drugs, 2008, 9(8), 899-912.

4. Masthanamma S K and Alekya G, Int J Pharm Sci Res., 2014, 5(2), 483-489.

5. Girija B, Bhavar Sanjay S, Pekamwar K B Aher, Sanjay R and Chaudhari, Amer J Pharm Tech Res., 2013, 3(1), 450- 458.

6. Somsubhra G, Kumar M, Jena S, Banji D and Roy S, Asian J Res Chem., 2012, 5(12), 1472-1475.

7. Venkata R, Rama Devi P and Mukkanti K, Int J Pharm Pharm Sci., 2012, 4(3), 975.

8. Else L, Watson V, John Tjia J, Hughes A, Siccardi M, Khoo S and Back D, $J$ Chromatogr B, 2010, 878(19), 1455-1465; DOI:10.1016/j.jchromb.2010.03.036

9. Mohana Reddy C, Hussain Reddy K, Narayanareddy P P and Venkataramana M, Int J Cl. Pharm Therapy Toxicology, 2012, 1, 1-8; http://scidoc.org/articlepdfs/IJCPT/IJCPT-2167-910X\%20-01-101.pdf

10. Shibata M, Takahashi M, Yoshino M, Kuwahara T, Nomura, T, Yokomaku Y and Sugiura W, J Med Invest., 2013, 60(1-2), 35-40.

11. Addepalli V, Raju and Raju Nemala A, Asian J Bio Pharm Sci., 2013, 3(21), 23-29; DOI:10.15272/ajbps.v3i21.293

12. Sandeep K, Madhusudhana Reddy I and Sudhakar M, Adv Pharm Bull., 2013, 3(2), 469-472.

13. Arayne M S, Sultana N and Siddiqui F A, Pak J Pharm Sci., 2007, 20(2), 100-106. 